\author{
Blanka Kudláčová \\ Uniwersytet Trnawski \\ w Trnawie
}

\title{
Paradygmaty w rozwoju europejskiego myślenia pedagogicznego
}

René Rémond w swojej publikacji Religia $i$ społeczeństwo w Europie pisze:

\begin{abstract}
Europa wyrasta nam przed oczyma. I to jest wielka nadzieja. Do jej spełnienia dojdzie jednak tylko wtedy, gdy nie pozbawimy jej przeszłości. Bez niej Europa zostałaby biedną sierotą ${ }^{1}$.
\end{abstract}

Dzieje Europy możemy zrozumieć tylko wtedy, jeśli nie będziemy ich badać w izolacji od dziejów światowych. W takim kontekście ukażą się nam cechy typowe dla dziejów europejskich, cechy, które ową „europejskość“ wytwarzają, a myślenie i kulturę europejską określają względem innych środowisk i kultur geograficznych. Europa nie jest to tylko środowisko geograficzne, jest czymś więcej. Według P. den Boera Europa stała się ideą, która zaczęła nabierać jaśniejszych kształtów dzięki refleksjom z początku XIX stulecia o jej istocie i powstaniu ${ }^{2}$. Człowiek nie jest w stanie badać dziejów europejskich jako całości, może analizować tylko poszczególne dziedziny myślenia ludzkiego i praktyki. Może się okazać, że badanie poszczególnych części będzie niepełne, skoro zostanie wyrwane z kontekstu. Nasze możliwości pozwalają nam badać tylko pewien wycinek dziejów europejskich w tematycznym lub czasowym ograniczeniu. W efekcie przedmiotem naszych badań jest rozwój myślenia pedagogicznego typowego dla Europy, czyli europejskiego. Wiele z tego, co zostanie tu powiedziane, może nie jest nowe, ale jest to próba szukania odpowiedzi na pytania człowieka na początku XXI stulecia. Właściwie chodzi o pytania filozoficzne, które zdaniem Pospíšila pojawiają się w nowych formach i wymagają nowych odpowiedzi ${ }^{3}$. Badanie myśli pedagogicznej jest ciągłą i powtarzaną próbą badań nad ludzkim myśleniem, rozumieniem i „tłumaczeniem” człowieka oraz jego zamiaru wywierania wpływu na samego siebie, innych i otaczający go świat. Chodzi o proces badania, który jest często niejednoznaczny i pełen

\footnotetext{
${ }^{1}$ R. Rémond, Náboženství a společnost v Evropě, Praha 2003, s. 5.

${ }^{2}$ P. den Boer, Stručné dějiny Evropy, Blansko 2003.

${ }^{3}$ J. Pospíšil, Filosofická východiska cílů v obdobi novověkého obratu, Olomouc 2009.
} 
niespodzianek. Znalezienie nowych obszarów rzeczywistości otwiera nowe pytania i możliwości dla kolejnych korekt i obiektywizacji historii praktyki tudzież teorii pedagogicznej. Potwierdza to również opinia S. Sztobryna, który twierdzi, że efektem takiego badania może być

nie tylko obserwacja historycznego narastania określonych koncepcji i ich interpretacji, ale także stworzenie swoistej mapy typów i poziomów rekonstrukcji oraz różnego rodzaju błędów i zafałszowań, które w tych interpretacjach są ukryte ${ }^{4}$.

Historyczno-filozoficzna refleksja umożliwia ciągłą krytyczną ocenę pedagogiki jako nauki i zarazem stwarza możliwości i przestrzeń dla szukania odpowiedzi na pytania związane z jej teraźnieszym ukierunkowaniem i oceną jej przedmiotu oraz metodologii. Twierdzenie o końcu znaczenia filozofii i histori dla pedagogiki nie sprawdziło się, wręcz odwrotnie. Potwierdzają to również słowa czeskiego pedagoga, J. Skalkovej:

Nauka nie może unikać swojej historii, odrzucać swojej przeszłości, ani rezygnować z refleksji nad swoją metodologią. Do jej istoty należy podjęcie wysiłku, który pokaże, co trzeba odrzucić, co trzeba uznać za inspirujące, aby można było dalej, w nowych warunkach, ją rozwijać i integrować w całość wiedzy ${ }^{5}$.

Wykorzystując historyczno-filozoficzne podejście i refleksję, nie musimy bać się nieustannej dyferencjacji i specjalizacji nauk o wychowaniu ani też pluralizmu teorii wychowania i kształcenia, który stał się „,czymś oczywistym i naturalnym“"

\section{Zmiany paradygmatu w rozwoju myślenia pedagogicznego w Europie}

Na podstawie naszych badań, orientowanych na teoretyczne przesłanki myśli pedagogicznej i ich aplikację $\mathrm{w}$ kontekście europejskim ${ }^{7}$, rozpatrywaliśmy charakter wychowania i kształcenia w poszczególnych okresach dziejów europejskich. Próbowaliśmy znaleźć typową charakterystykę, która przyniosła pewne novum i zwyciężyła poprzednią, ale nie chcemy powiedzieć, iż charakter wychowania i kształcenia zmienił się zupełnie. Takie podejście pozwoliło nam ustalić pewną etapizację rozwoju myśli pedagogicznej w Europie, w której położyliśmy

${ }^{4}$ S. Sztobryn, Historiografia edukacyjna i jej metodologia. Wybrane zagadnienia, [w:] S. Palka (red.), Podstawy metodologii badań w pedagogice, Gdańsk 2010, s. 303.

${ }^{5}$ J. Skalková, Pedagogika a výzvy nové doby, Brno 2004, s. 25.

${ }^{6}$ B. Śliwerski, Współczesna myśl pedagogiczna (Znaczenia, klasyfikacje, badania), Kraków 2009 , s. 8.

${ }^{7}$ Szczegółowo popatrz: B. Kudláčová (ed.), Európske pedagogické myslenie - od antiky po modernu, Trnava 2010. 
akcent na, z naszego punktu widzenia najważnejszą, charakterystykę wychowania i kształcenia. Wyróżniliśmy pięć takich charakterystyk, które odpowiadają pięciu etapom.

\subsection{Uniwersalizacja wychowania i kształcenia}

Wczesny etap wiąże się z czasami antyku i jest kontynuacją okresu chrześcijańskiej starożytności i średniowiecza. Wówczas powstały pierwsze teorie pedagogiczne, pierwsze zorganizowane i instytucjonalizowane systemy wychowania i kształcenia oraz program (curriculum) kształcenia europejskiego, znane jako siedem sztuk wyzwolonych. Dla tego okresu jest charakterystyczne, iż wychowanie ma już intencjonalny charakter. W związku z ówczesnym rozumieniem człowieka możemy mówić o początkach wolnych jego decyzji i o początkach indywidualizmu w wychowaniu i kształceniu. Cel wychowania jest ustanawiany i określany z zewnątrz, ma ono charakter uniwersalny i jest metafizycznie zakotwiczone. Wbrew temu, że w tym czasie istniały już pierwsze systemy pisma, najważniejszym medium było mówione słowo, które również decydowało o strukturze społeczeństwa i myślenia. Na kształcenie myślenia, w tym także myślenia pedagogicznego, wpływ miało prawo sakralne, resp. prawo obywatelskie. Za pośrednictwiem edukcji przekazywano pewne „niezmienne wartości” i człowiek podporządkowywał swoje życie i myślenie ówczesnym wyobrażeniom o świecie. Nie chodziło o moc i wpływ na świat, ale na siebie. Dla tego okresu typowy był konflikt dwóch pryncypialnie różnych celów i modelów edukacji: filozoficznego, który moglibyśmy nazwać świeckim, i chrześcijańskiego, który możemy nazwać religijnym ${ }^{8}$. W pierwszych stuleciach po Chrystusie te dwa modele wchodzily w konflikt, do ich harmonizacji doszło dopiero w klasycznym okresie scholastyki. Według R. Rémonda, poczynając od zrównania praw chrześcijaństwa i kultów pogańskich (w roku 313) oraz uznania chrześcijaństwa za religię państwową w Imperium Rzymskim (w roku 391), Europa staje się chrześciajańska - jako jedyna ze wszystkich kontynentów, co również wywarło wpływ na charakter wychowania i kształcenia9.

\subsection{Pluralizacja wychowania i kształcenia}

Kolejny etap zaczyna się okresem humanizmu i renesansu. Dla tego czasu charakterystyczna jest zmiana, którą jest koniec monopolu Kościoła katolickiego. Schizma zachodnia (drugi ważny podział religijny w Europie) spowodowała powstanie pluralizmu $\mathrm{w}$ chrześcijaństwie i oznaczała koniec kształcenia

\footnotetext{
${ }^{8}$ L. Bokorová, Krestanstvo a klasický model vzdelávania, [w:] B. Kudláčová (ed.), Topológia človeka vo vztahu $k$ výchove a vzdelávaniu v európskej tradícii, Trnava 2008.

${ }^{9}$ R. Rémond, Náboženství a společnost...
} 
uniwersalnego w Europie. Był to zarazem koniec do tej pory relatywnie uniwersalnej Europy. Poszczególne narody zaczynają sobie wówczas uświadamiać swoją specyfikę i tożsamość, pojawiają się konflikty między nimi i walka o dominację zaczyna przybierać nowe oblicza. Dla tego okresu typowy jest wyraźny zwrot ku człowiekowi - antropocentryzm i odnalezienie autonomicznego Ja. W dziedzinie myśli pedagogicznej pojawiają się silne osobowości, co wiązane jest z jej dywersyfikacją. W etapie tym nastąpił rozwój autentycznej myśli i teorii pedagogicznej, co wiązało się z powstaniem nowych teorii wychowania i podejść teoretycznych, jako przesłanek dla praktyki edukacyjnej. Cel wychowania nie był już definiowany z zewnątrz. W tym okresie możemy mówić o emancypacji edukacji spod silnego wpływu religijnego i o początkach sekularyzacji w Europie. Zadanie słowa jako medium przejmuje pismo, które zaczyna odgrywać wielką rolę. I z tym związana jest kolejna ważna zmiana w myśleniu człowieka - oddalenie podmiotu (autora) od jego dzieła, które zaczyna być reprodukowane w krótkim czasie w wielkich ilościach.

\subsection{Laicyzacja wychowania i kształcenia}

Trzeci etap historycznie związany jest z okresem oświecenia. Do najbardziej zasadniczych zmian tych czasów można zaliczyć rozwój nauk przyrodniczych i myślenia krytyczno-empirycznego, a także dalsze oziębienie relacji religii i państwa. Wiara przestaje być warunkiem obywatelstwa, zaczyna być prywatną sprawą i kwestią wolnej decyzji człowieka. To z kolei prowadziło do laicyzacji wychowania i kształcenia. Ukierunkowanie na człowieka osiąga szczyt: ogóĺna idea godności człowieka i związana z nią jego wolność, zostały zapisane $\mathrm{w}$ konstytucjach prawnych $\mathrm{w}$ formie ogólnych praw człowieka. Człowiek chce zapanować nie tylko nad sobą, ale również nad światem i przyrodą, lecz nie w sensie biblijnym a pragmatycznym. Legitymizacją tego były rezultaty badań w zakresie nauk przyrodniczych i obiektywnego poznania zachodzących w nich procesów. Człowiek sam siebie rozumiał jako podmiot, który jest w stanie realizować własne ,urzeczywistnienie”, podobnie jak zmianę otaczającego go świata. Tym samym rosła jego pewność siebie, poczucie wolności i wartości. Wychowanie i kształcenie definitywnie utraciły metyfizyczny i uniwersalny charakter. Społeczeństwo zaczęło się tworzyć na podstawie umowy jednostek, nie występowało już jako całość górująca nad jednostką. Ważną zmianą w dziedzinie edukacji stały się obowiązek szkolny i kształcenie realizowane $\mathbf{w}$ państwowych szkolnych systemach $\mathrm{w}$ poszczególnych krajach europejskich, dostępnych dla wszystkich obywateli państwa. Wychowanie i kształcenie traktowane były instrumentalnie, przygotowywały człowieka do radzenia sobie w realnym świecie. Czasy te przyniosły początek nowoczesnego wychowania i kształcenia: nowe państwowe systemy szkolne stały się dostępne 
dla wszystkich warstw ludności, wprowadzono bowiem obowiązek szkolny. Idea ogólnego kształcenia w okresie oświecenia wbrew swoim pozytywom przyniosła też jednak ze sobą możliwości nadużyć i ideologizacji edukacji, co ujawniło się głównie w późniejszych czasach. W czasach tych odnotowujemy również początek zorganizowanego kształcenia nauczycieli. W dziedzinie edukacji ludzi z upośledzeniem zaczyna się systematycznie organizowana instytucjonalna i fachowa opieka, podejmowane są pierwsze próby tworzenia koncepcji opiekuńczych.

\subsection{Instytucjonalizacja wychowania i kształcenia}

Czwarty etap w rozwoju edukacji zaczyna się w wieku XIX, na który datowane są początki pedagogiki jako nauki. Myśl pedagogiczna ewoluuje za pośrednictwem nowych kierunków i teorii pedagogicznych. W pedagogice narasta refleksja krytyczna i upowszechniają się badania empiryczne. Wychowanie i kształcenie są instytucjonalizowane, każdy cywilizowany kraj ma własny system edukacji, związany na jego polityką i ekonomią. Wiek XIX jest „kompleksową i wykoncypowaną identyfikacją Europy z uczonością" ${ }^{10}$. Człowiek zaczyna uważać siebie za pana przyrody i wszystkostanowiący podmiot, ale to wiedzie do jego urzedmiotowienia i, paradoksalnie, staje się przedmiotem manipulacji. Na przełomie wieków XIX i XX powstają reformatorskie ruchy pedagogiczne, które zorientowane są na dziecko. Około roku 1905 odnotowano we Francji bardzo silną tendencję do oderwania społeczeństwa od Kościoła. Nowoczesna instytucjonalizacja i sekularyzacja, które miały człowiekowi zapewnić wolność od wpływu religii, przywiodły go do nowej zależności - związanej z dominacją politycznych doktryn w poszczególnych państwach. Systemy edukacyjne często stawały się narzędziem ideologii - np. jednolita szkoła sowiecka, pedagogika faszyzmu we Włoszech, pedagogika narodowo-socjalistyczna w Niemczech. Na wychowanie i kształcenie wywierały wpływ pozytywizm i sekularyzm, które starały się kształtować człowieka i jego życie. W okresie tym triumfuje rozwój człowieka "masowego”, stającego się „zmiennym”. Powstaje sfera zagospodarowania wolnego czasu, jako samodzielny sektor, który pośrednictwem przy ofiarowanych usługach przyczynia się do zaspokojenia potrzeb różnych warstw społeczeństwa $\mathrm{w}$ ich wolnym czasie ${ }^{11}$. Etap ten osiąga apogeum w latach 60 . wieku XX, kiedy możemy mówić o kryzysie wychowania i kształcenia europejskiego, co odzwierciedliło się również w teoriach pedagogicznych negowania szkoły (deskolaryzacji) i antypedagogiki.

\footnotetext{
${ }^{10}$ P. den Boer, Stručné dějiny Evropy...

${ }^{11}$ P. Lenčo, Vývoj výchovy vo volnom čase, [w:] B. Kudláčová (ed.), Európske pedagogické myslenie (od antiky po modernu), Trnava 2010.
} 


\subsection{Ekonomizacja wychowania i kształcenia}

Piąty etap zaczyna się wspomnianym już wyżej kryzysem pedagogiki. Ideowo jest kszałtowany przez myślenie postmodernistyczne. Niektórzy filozofowie w drugiej połowie wieku XX postrzegają człowieka jako jednostkę, która staje się obca przyrodzie i własnej tożsamości, staje się wolna i niezależna, a jednocześnie ponownie szuka kontaktu ze światem i ze sobą samą oraz uświadamia sobie, że wolność jest dla niej brzemieniem. Nowe poczucie niezależności wywołuje w niej wrażenie samotności, izolacji, niepewności i lęku. E. Fromm jakby przewidział wizje człowieka końca wieku $\mathrm{XX}^{12}$. W swojej książce Ucieczka od wolności pisze, iż wydawało się, że pełne pokazanie możliwości człowieka jest celem, do którego rozwój społeczeństwa szybko się przybliża. Założenia liberalizmu ekonomicznego, demokracji politycznej, wolności religijnej i indywidualizmu w życiu osobistym były przejawem dążenia do wolności i jednocześnie wydawało się, iż przybliżają człowieka do jego samorealizacji. Człowiek niszczył jedną więź za drugą, odrzucił władzę przyrody i sam siebie ustanowił jej panem; odrzucił dominację Kościoła i dokonał przewrotu państwa absolutystycznego. Usunięcie zewnętrznej władzy wydawało się nie tylko koniecznością, ale i warunkiem osiągnięcia celu, którym jest wolność człowieka. Jednak wspomniana niezależność zaczęła wywoływać w człowieku poczucie wyobcowania, zagubienia, wątpliwości i niepokoju.

W latach 80. i 90. wieku XX zaczęto w krajach Europy zachodniej, w dziedzinie pregradualnego przygotowania pedagogów, kłaść akcent na konkretne kompetencje nauczyciela, na „technikę” jego kształcenia i marginalizację przygotowania teoretycznego, co D. Crook charakteryzuje jako atak na teoretyczne aspekty studiów pedagogicznych ${ }^{13}$. Na margines zainteresowania wypadły również badania $\mathrm{w}$ dziedzinie nauk o wychowaniu ${ }^{14}$. Stan ten był spowodowany z jednej strony krytyką klasycznego historyzmu w drugiej połowie wieku XX, przy czym zakwestionowana została wartość historii i jej przedmiotu, ale również izolacją filozofii od pedagogiki. Pedagogiką, według W. Carra, interesowały się tylko małe, zamknięte koła naukowe, a rezultaty ich badań miały minimalny wpływ na politykę i praktykę edukacyjną ${ }^{15}$. W krajach Europy wschodniej po zastosowaniu zasad materializmu historycznego do metodologii wszystkich nauk (szczególnie nauk społecznych i humanistycznych), po bezkrytycznym podejściu do różnych teorii wychowania i nauczania, orientacji na cząstkowe badania empiryczne, w nauce pedagogicznej końca lat 90 . XX i na początku wieku XXI brakowało wybitnych

${ }^{12}$ E. Fromm, Strach ze svobody, Praha 1993.

${ }^{13}$ D. Crook, Educational studies and teacher education, „British Journal of Educational Studies" 2002, vol. 50, No 1.

${ }^{14}$ G. McCulloch, History of education, [w:] G. McCulloch, D. Crook (eds), The Routledge International Encyclopedia of Education, London-NewYork 2008.

${ }^{15}$ W. Carr, Philosophy and Education, ,Journal of Philosophy of Education” 2004, vol. 38, No 1. 
publikacji, które mógłyby ją definiować w nowej sytuacji historycznej, a pedagogom ułatwiłyby szukanie odpowiedzi na podstawowe pytania dotyczące sensu, istoty i celu wychowania.

Wbrew różnym kierunkom rozwoju w zachodniej i wschodniej części Europy wytworzyła się sytuacja, iż i tu i tam grupy polityków, nauczycieli i urzędników podejmują i realizują ważne decyzje w dziedzinie polityki i praktyki edukacyjnej bez głębszej filozoficzno-historycznej refleksji i świadomości ich konsekwencji. Polityka edukacyjna w Europie w ostatnich trzech dekadach wieku XX realizowała mnóstwo szybkich reform, z pominięciem wiedzy filozoficznej i historii wychowania oraz kształcenia. Ignorowała bogactwo doświadczeń praktyki edukacyjnej, kierując się często tylko chęcią spełnienia norm i technokratycznych nakazów Unii Europejskiej, ewentualnie rozwiązywaniem sztucznie tworzonych problemów, bardzo kosztownym finansowo.

\section{Zakończenie}

W październiku odbyła się konferencja Konteksty filozofi wychowania w historycznej $i$ wspótczesnej perspektywie, która organizowana była przez Katedrę Studiów Pedagogicznych Wydziału Pedagogicznego na Uniwersytecie w Trnawie we współpracy z Towarzystwem Pedagogiki Filozoficznej i Wydziałem Pedagogicznym Uniwersytetu Karola w Pradze. W wielu referatach zadawano otwarte pytania, odnoszące się do wychowywania we współczesnym transmodernistycznym okresie. Myślę, że już samo zadanie tych pytań jest wielkim sukcesem, nie możemy bowiem obiektywnie ocenić czasu, w którym żyjemy, można to zrobić dopiero z jakiejś perspektywy. Musimy jednak wychowywać generację przyszłych pedagogów i innych fachowców dla przyszłości, która jeszcze nie istnieje, którą człowiek sam dopiero tworzy ${ }^{16}$.

W odniesieniu do współczesności mamy takie możliwości i wolność, jakimi człowiek nigdy w historii nie dysponował, z drugiej zaś strony człowiek żyje w takiej niepewności (mentalnej), jakiej do tej pory nie znał. J. Poněšický widzi nowe zagrożenia dla wolności w utracie zakotwiczenia, jak i w tym, że wszystko jest obecnie dozwolone: człowiek ciągle stoi przed wyborem między alternatywami, biorąc odpowiedzialność za decyzje, których skutków nie potrafi często przewidzieć $^{17}$. Jako odpowiedź na taką charakterystykę naszych czasów wykorzystam słowa, które zabrzmiały na wspomnianej wyżej konferencji: „sytuacja ta stanowi

${ }^{16}$ B. Kosová, Filozofia ako východisko univerzitného vzdelávania učitel'ov a pedagógov, [w:] B. Kudláčová, S. Sztobryn (eds), Kontexty filozofie výchovy v historickej a súčasnej perspektive, Trnava 2010.

${ }^{17}$ J. Poněšický, Člověk a jeho postaveni ve světě, Praha 2006. 
wyzwanie dla wychowania: nauczyć się żyć z niepewnością, bez zabezpieczania się, uczyć się osiągać harmonię w warunkach >ruchomych piasków<".

W przypadku współczesnej pedagogiki konieczne są solidne filozoficzne podstawy, a jednocześnie filozofia musi być powiązana z żywą praktyką wychowania. Wychowanie jako praktyczna działałność ma filozoficzną proweniencję, pochodzenie to jest głębsze niż jego poszczególne oblicza w historii, z okresami wykorzystywania nauczania do niewłaściwych celów. Mówiąc słowami P. Hogana praktyka edukacyjna nie będzie wolna od wykorzystywania (niezależnie od tego, czy chodzi o Kościół, państwo, pieniądze, normy europejskie), musi jednak być odpowiedzialna za swoje rzeczywiste osiągnięcia, które trzeba odróżnić od celów narzucanych z góry lub z zewnątrz ${ }^{18}$. I to jest wystarczająca wewnętrzna siła i nadzieja, która wywodzi się bezpośrednio z samej istoty wychowania jako takiego.

${ }^{18} \mathrm{P}$. Hogan, Historické dedičstvo poručnictva a jeho prejavy v edukačnej praxi v pohl'ade 21. storočia, [w:] B. Kudláčová, S. Sztobryn (eds), Kontexty filozofie výchovy... 